University of New Hampshire

University of New Hampshire Scholars' Repository

5-15-1996

\title{
Recent climate anomalies and their impact on snow chemistry at South Pole, 1987 - 1994
}

Jack E. Dibb

University of New Hampshire, jack.dibb@unh.edu

Sallie I. Whitlow

University of New Hampshire - Main Campus

Follow this and additional works at: https://scholars.unh.edu/earthsci_facpub

Part of the Atmospheric Sciences Commons

\section{Recommended Citation}

J. E. Dibb and S. I. Whitlow, "Recent climate anomalies and their impact on snow chemistry at south pole, 1987-1994," Geophysical Research Letters, vol. 23, no. 10, pp. 1115-1118, May 1996.

This Article is brought to you for free and open access by the Earth Sciences at University of New Hampshire Scholars' Repository. It has been accepted for inclusion in Earth Sciences Scholarship by an authorized administrator of University of New Hampshire Scholars' Repository. For more information, please contact Scholarly.Communication@unh.edu. 


\title{
Recent climate anomalies and their impact on snow chemistry at South Pole, 1987 - 1994
}

\author{
Jack E. Dibb and Sallie I. Whitlow \\ Glacier Research Group, Institute for the Study of Earth, Oceans and Space, University of New Hampshire, Dumam
}

Abstract. Three 2-m deep snowpits sampled at South Pole in 1994 provide detailed (2-cm resolution) profiles of the concentrations of soluble ionic species for the period 1987 1994. The most prominent feature is a large concentration spike of $\mathrm{SO}_{4}=$ in snow deposited in 1992 reflecting fallout from the eruptions of Pinatubo and Hudson in 1991. Concentrations of MSA and values of the MSA/(non-sea-salt $\mathrm{SO}_{4}{ }^{2}$ ) ratio are elevated for about three years centered on the prominent volcanic signal. These changes appear to be due to the extended 1991 - $1993 \mathrm{El} \mathrm{Nino.} \mathrm{The} \mathrm{overlapping} \mathrm{effects} \mathrm{of}$ the volcanic eruptions and $\mathrm{El}$ Nino circulation preclude partitioning the enhanced deposition of $\mathrm{SO}_{4}=$ into volcanic and biogenic fractions. Nitrate concentration profiles show no relation to the severity of $\mathrm{O}_{3}$ depletion in the Antarctic stratosphere during the period of record. Rather, the profiles show a progressive decline of the annual peak concentrations over the top $0.5-1.0 \mathrm{~m}$ of each pit. This behavior is attributed to post-deposition loss of $\mathrm{NO}_{3}{ }^{-}$, presumably by reemission of $\mathrm{HNO}_{3}$ into the atmosphere.

\section{Introduction}

Evidence is mounting that anthropogenic activities have dramatically altered the composition of the atmosphere, thereby modifying the climate system. Projections of future changes must be based on sound understanding of how the system functioned before the anthropogenic era. There is thus increasing interest in "calibrated" proxy records of key climate parameters. Records contained in the snow and ice of the polar ice sheets contain highly detailed information about the past composition of the atmosphere. However, the calibration of many of these proxy records is still in progress.

The first 5 years of the 1990s are characterized by several global-scale climate anomalies. The eruption of Pinatubo in June, 1991, followed by the smaller eruption of Hudson in August, resulted in the largest volcanic perturbation of stratospheric $\mathrm{SO}_{4}=$ in this century. It has been suggested that the volcanic aerosol clouds played a major role in the severity of the 1991 and 1992 Antarctic $\mathrm{O}_{3}$ holes, and contributed to the record low $\mathrm{O}_{3}$ measured there in spring, 1993. The 1991 1993 interval was also unusual in that E1 Nino circulation patterns persisted throughout. Previous work has suggested that the snow on the Antarctic Plateau preserves a sensitive record of all three of these climate anomalies (volcanic eruptions, the Antarctic $\mathrm{O}_{3}$ hole, and $\mathrm{El} \mathrm{Nino} \mathrm{events).} \mathrm{In} \mathrm{this}$ paper, we describe the chemical signals of these climate

Copyright 1996 by the American Geophysical Union.

Paper number 96GL01039

0094-8534/96/96GL-01039\$05.00 anomalies in the early 1990 s as they were recorded in three snowpits at South Pole.

\section{Methods}

In November, 1994, three snowpits were sampled at different sites, each approximately $10 \mathrm{~km}$ removed from Amundsen-Scott South Pole station. All pits were sampled at $2-\mathrm{cm}$ resolution to $2-\mathrm{m}$ depth. Samples were collected into precleaned polyethylene containers for frozen shipment back to our laboratory and stored below $-15^{\circ} \mathrm{C}$ until melting immediately prior to analysis. Concentrations of soluble ionic species were determined by ion chromatography. Previously established seasonal variations in the concentrations of $\mathrm{Na}^{+}$(winter peak), $\mathrm{NO}_{3}{ }^{-}$(spring-summer peak), and the $\mathrm{Cl}^{-} / \mathrm{Na}^{+}$ratio (summer peak) [Whitlow et al., 1992] were used to date each pit.

\section{Results}

Comparison of the 3 new pits to a 1988 pit (located 4 times further from the station in the upwind direction [Whitlow et al., 1992]) reveals overall similarity (Table 1), indicating that snow composition in the new pits has not been strongly impacted by local pollution. Concentrations of $\mathrm{Ca}^{2+}$ (reflecting continental dust) average 6-fold lower in the 1994 pits than the 35-year mean from the earlier pit. Whitlow et al. [1992] observed that $\mathrm{Ca}^{2+}$ concentrations during the 1980's were already significantly lower than they had been between 1955 and about 1975 . Our results indicate a continuation of this downward trend.

The concentrations of sea-salt-derived species $\left(\mathrm{Na}^{+}, \mathrm{Mg}^{2+}\right.$ and $\left.\mathrm{Cl}^{-}\right)$are also lower in the 1994 pits. Decreases of $\mathrm{Na}^{+}$and $\mathrm{Mg}^{2+}$ were already hinted at by comparing the 1980 's mean (approximated by the top $2 \mathrm{~m}$ ) to the complete record in the 6$\mathrm{m}$ pit (Table 1). On the other hand, $\mathrm{Cl}^{-}$concentrations increased slightly in the top of the 1988 pit. Such an increase toward the surface was unique to $\mathrm{Cl}^{-}$and $\mathrm{NO}_{3}{ }^{-}$. The $\mathrm{NO}_{3}{ }^{-}$ concentrations in our new pits provide mixed comparisons to the 1988 pit, with means in pits 1 and 2 higher than was observed for the 1980s in the earlier record, while the pit 3 mean is slightly less than the 1988 6-m average (Table 1).

\section{Discussion}

\section{Ozone Depletion and South Pole Nitrate Records}

Concentrations of non-sea-salt (nss) $\mathrm{Cl}^{-}$and $\mathrm{NO}_{3}{ }^{-}$in snow on the Antarctic Plateau appear to be determined by $\mathrm{HCl}$ and $\mathrm{HNO}_{3}$ in the overlying atmosphere. There is increasing evidence that these acids can return to the atmosphere if decreasing atmospheric concentrations result in supersaturated concentrations in the snow [DeAngelis and Legrand, 1995 and 
Table 1. Summary of the soluble ionic composition of snow from 4 South Pole pits. All concentrations in neq $\mathrm{g}^{-1}$. The three new pits were all $10 \mathrm{~km}$ from the station, while the 1988 pit was $40 \mathrm{~km}$ away.

$$
\mathrm{Na}^{+} \mathrm{NH}_{4}^{+} \mathrm{K}^{+} \quad \mathrm{Mg}^{2+} \mathrm{Ca}^{2+} \mathrm{Cl}^{-} \mathrm{NO}_{3}^{-} \mathrm{SO}_{4}=\mathrm{MSA}
$$

\begin{tabular}{|c|c|c|c|c|c|c|c|c|}
\hline & & Pit 1 & Grid directio & $150^{\circ}$ & 1987 & 1994 & & \\
\hline mean & 0.26 & 0.05 & $0.01 \quad 0.07$ & 0.03 & 0.72 & 1.89 & 1.32 & 0.12 \\
\hline std. dev. & 0.21 & 0.03 & $0.01 \quad 0.07$ & 0.02 & 0.33 & 0.68 & 0.59 & 0.11 \\
\hline median & 0.20 & 0.05 & $0.01 \quad 0.05$ & 0.03 & 0.61 & 1.74 & 1.19 & 0.09 \\
\hline & & Pit 2 & Grid directic & $230^{\circ}$ & $1987-$ & 1994 & & \\
\hline mean & 0.26 & 0.08 & $\begin{array}{ll}0.01 & 0.07\end{array}$ & 0.04 & 0.67 & 2.03 & 1.32 & 0.14 \\
\hline std. dev. & 0.19 & 0.04 & $0.01 \quad 0.05$ & 0.02 & 0.30 & 1.03 & 0.53 & 0.09 \\
\hline median & 0.23 & 0.07 & 0.010 .06 & 0.03 & 0.63 & 1.84 & 1.23 & 0.11 \\
\hline & & Pit & (Grid directi & $\left.45^{\circ}\right)$ & 1986 - & 1994 & & \\
\hline mean & 0.34 & 0.07 & $0.02 \quad 0.09$ & 0.03 & 0.77 & 1.49 & 1.39 & 0.09 \\
\hline std. dev. & 0.30 & 0.03 & $0.02 \quad 0.08$ & 0.02 & 0.30 & 0.31 & 0.66 & 0.07 \\
\hline median & 0.28 & 0.07 & $0.01 \quad 0.08$ & 0.03 & 0.78 & 1.40 & 1.21 & 0.06 \\
\hline & & & 1988 Pit $^{*}, 0-$ & n 195 & -1988 & & & \\
\hline mean & 0.48 & 0.07 & $0.03 \quad 0.23$ & 0.21 & 0.96 & 1.59 & 1.30 & \\
\hline & & & $988 \mathrm{Pit}^{*}, 0$ & n 198 & -198 & & & \\
\hline mean & 0.43 & 0.06 & 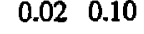 & 0.07 & 1.02 & 1.76 & 1.27 & \\
\hline
\end{tabular}

* From Whitlow et al., 1992

references therein]. This loss by re-equilibration is moderated by the rate of snow accumulation, with greater losses possible where low accumulation keeps a given layer of snow in "contact" with the atmosphere for longer periods [DeAngelis and Legrand, 1995].

In all of our South Pole pits the concentration of $\mathrm{NO}_{3}{ }^{-}$in the annual spring peaks increases toward the surface (Fig. 1). Mayewski and Legrand [1990] suggested that the 1988 profile reflected increasing depletion of $\mathrm{O}_{3}$ in the Antarctic polar vortex, with $\mathrm{NO}_{3}{ }^{-}$deposition at South Pole providing a proxy record of stratospheric denitrification by polar stratospheric clouds (PSCs). In particular, they noted that the highest $\mathrm{NO}_{3}{ }^{-}$ peak in the snow corresponded to spring 1987, the year of the deepest $\mathrm{O}_{3}$ hole measured up to that point. An updated listing of the annual minimum $\mathrm{O}_{3}$ column measured over Antarctica

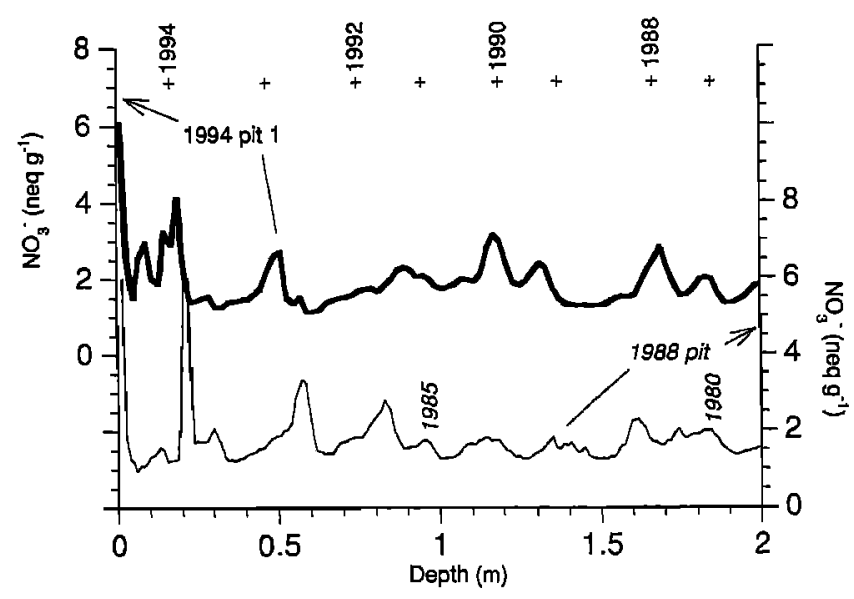

Figure 1. Depth profiles of $\mathrm{NO}_{3}{ }^{-}$concentration in snowpits sampled near South Pole in November, 1994 (thick line) and December, 1988 (thin line). Annual marks placed in summer snow are labeled to mark the beginning of each calendar year. by TOMS through 1993 has 1993, 1991, 1992, 1987, 1989, and 1990 in the top 6 positions [Herman et al., 1995]. Ozone column measurements extrapolated from $\mathrm{O}_{3}$ sonde flights at South Pole also identify these 6 years as those with the deepest $\mathrm{O}_{3}$ holes, but indicate more severe depletion in 1992 than 1991 [Hofmann and Oltmans, 1993; Hofmann et al., 1994].

Our $\mathrm{NO}_{3}{ }^{-}$profiles in the 1994 pits show no correspondence to the severity of $\mathrm{O}_{3}$ depletion (Fig. 1). Also, the very high $\mathrm{NO}_{3}{ }^{-}$concentrations in 1987 snow at $20 \mathrm{~cm}$ in 1988 are not apparent in the 1987 layer in any of the 1994 pits. We thus conclude that interpretation of $\mathrm{NO}_{3}{ }^{-}$profiles at South Pole must account for post-deposition losses like those discussed by DeAngelis and Legrand [1995]. Unfortunately, our present understanding of such processes is too limited to allow quantitative interpretation [Dibb et al., 1994; Wolff, 1995].

\section{Volcanoes, ENSO and South Pole Records of Aerosol-Associated $S$ Species}

The eruptions of Hudson and Pinatubo greatly increased the loading of stratospheric $\mathrm{SO}_{4}=$ aerosols over Antarctica during 1991 - 1993 [e.g., Cacciani et al., 1993; Hofmann et al., 1994; Saxena, et al., 1995]. These particles enhanced $O_{3}$ depletion rates and the vertical extent of $\mathrm{O}_{3}$-free air in the Antarctic stratosphere, with the Pinatubo cloud specifically implicated as playing a major role in the depth of the $1992 \mathrm{O}_{3}$ hole [Hofmann and Oltmans, 1993] and contributing to the record low $\mathrm{O}_{3}$ measured in 1993 [Hofmann et al., 1994].

All of our pits contain a prominent nss $\mathrm{SO}_{4}$ concentration spike in the layers deposited near the end of 1992 (Fig. 2). It is not clear whether the enhanced $\mathrm{SO}_{4}{ }^{=}$deposition represents a combination of fallout from the two eruptions, or just the much larger Pinatubo event. Observations by SAGE II [Saxena et al., 1995] and a lidar at South Pole [Cacciani et al, 1993] indicate that two separate plumes were present in the Antarctic stratosphere late in 1991 . The cloud attributed to Hudson was centered at $10 \mathrm{~km}$ altitude over South Pole beginning in September and disappeared by the end of January, 1992. The Pinatubo cloud arrived over South Pole later in 1991, was initially restricted to altitudes $>20 \mathrm{~km}$ but descended to about $14 \mathrm{~km}$ by June, 1992. Some of the Hudson $\mathrm{SO}_{4}=$ aerosol must have deposited to the snow, but we suspect that the bulk of the late 1992 nss $\mathrm{SO}_{4}=$ signal represents deposition from the Pinatubo cloud. For convenience, we will refer to this feature as the "Pinatubo spike", but possible contributions from Hudson should be borne in mind.

The Pinatubo spike in our three nss $\mathrm{SO}_{4}{ }^{2}$ records is comparable to the $\mathrm{SO}_{4}{ }^{\mathrm{I}}$ enhancement in South Pole snow following the eruption of Agung (Fig. 2). Various estimates of emissions indicate that Pinatubo produced about 3-fold more $\mathrm{SO}_{2}$ than Agung [e.g., Cacciani et al., 1993], thus we would expect a proportionately larger signal in the snow. Recent work has suggested that the Agung signal preserved in snow at several Antarctic sites tends to be anomalously large compared to independent estimates of the perturbation of the stratospheric $\mathrm{SO}_{4}=$ layer by this eruption [Self and Zielinski, 1995]. We would therefore like to obtain a quantitative estimate of the increase in nss $\mathrm{SO}_{4}{ }^{2}$ deposition at South Pole that can be attributed to the volcanic eruptions in 1991 .

The Pinatubo spike is superimposed on a period with elevated nss $\mathrm{SO}_{4}=$ concentrations that lasted $2-3$ years (Fig. 2). Part of this increase may represent diffuse volcanic fallout throughout 1991 - 1993 , but the contribution of biogenic $\mathrm{SO}_{4}=$ may also have increased at this time. 

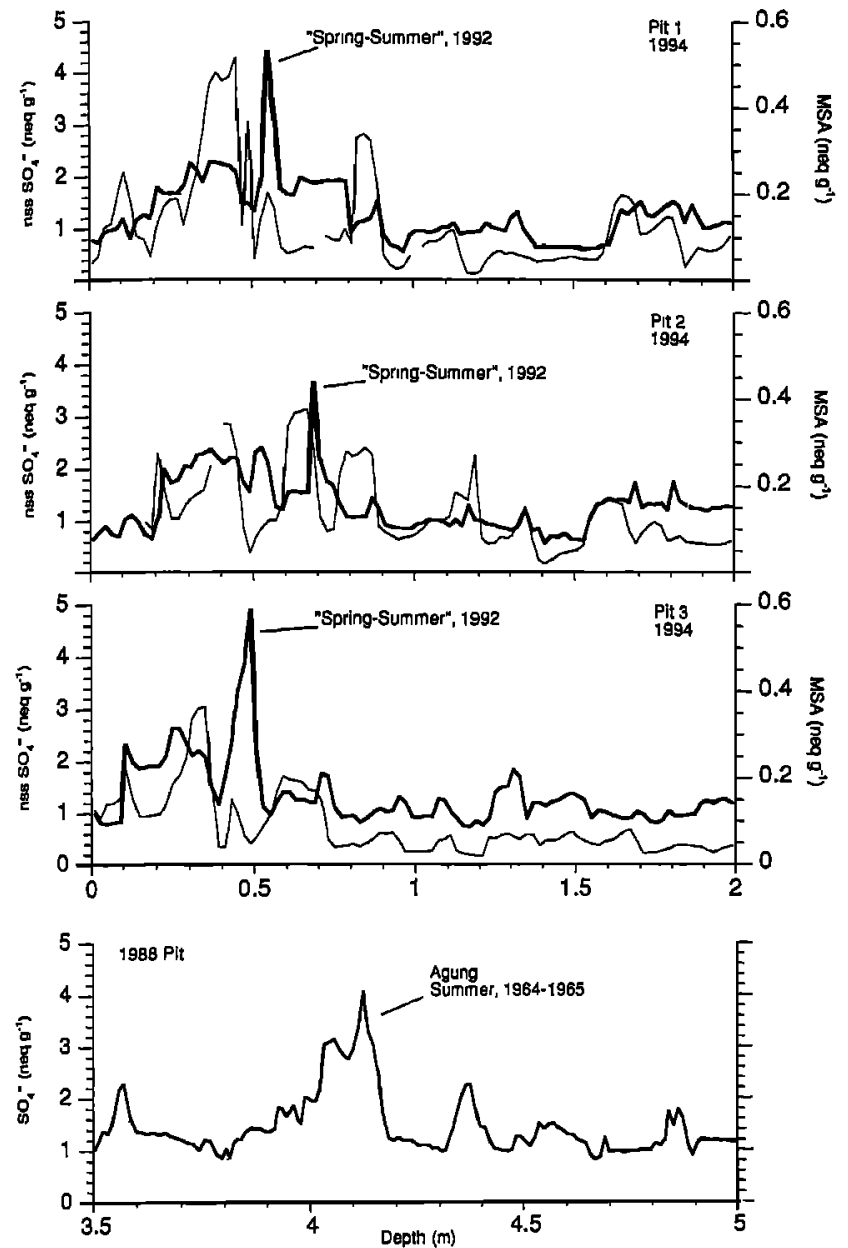

Figure 2. Depth profiles of nss $\mathrm{SO}_{4}=$ (thick lines) in the 3 1994 pits and in the portion of the 1988 pit that includes deposition of volcanic aerosols from the eruption of Agung. Concentrations of MSA are also shown in the 31994 pits (thin lines). The sub-vertical lines linking the upper 3 panels are time lines used to construct a 3-pit regional mean profile.

Since methylsulfonate (MSA) and biogenic $\mathrm{SO}_{4}=$ share the common dimethylsulfide precursor, we may be able to use MSA measurements to partition nss $\mathrm{SO}_{4}=$ into its biogenic and volcanic fractions. Legrand and Feniet-Saigne [1991] have shown that most sustained increases of MSA in South Pole snow are associated with the occurrence of El Nino circulation patterns. Elevated MSA concentrations during the extended 1991 - 1993 El Nino were therefore expected (Fig. 2). However, the coincidence of the extended $\mathrm{El} \mathrm{Nino} \mathrm{and} \mathrm{the}$ period of volcanic fallout makes partitioning of nss $\mathrm{SO}_{4}=$ more difficult. The problem lies in the fact that the molar ratio MSA/(biogenic $\mathrm{SO}_{4}{ }^{2}$ ) (denoted $\mathrm{R}^{*}$ ) apparently increases by a factor of $2-4$ between ordinary times and El Nino events, with no clear means to estimate the increase of $R^{*}$ in any given event [Legrand and Feniet-Saigne, 1991].

Examination of the ratio $\mathrm{MSA} /\left(\right.$ nss $\mathrm{SO}_{4}{ }^{-}$) (denoted $\mathrm{R}$ and equal to $\mathrm{R}^{*}$ only if all nss $\mathrm{SO}_{4}{ }^{=}$is biogenic) at both $2-\mathrm{cm}$ and yearly resolution revealed large differences between the three pits. To reduce this "spatial noise", we constructed a regional signal by averaging the profiles from the three pits. To place the records on a common depth (or time) scale, we assumed that 6 prominent features present in all of the nss $\mathrm{SO}_{4}=$ profiles reflected regional events (Fig. 2). We adjusted the depths between these time lines by linear stretching and compression, resulting in a 3-pit mean nss $\mathrm{SO}_{4}{ }^{2}$ profile that closely resembles each of the individual profiles (Fig. 3). The mean MSA profile constructed after this depth transformation captures the phasing of MSA variations in all of the pits, except in the vicinity of the Pinatubo spike. The magnitude of MSA variations is not at all consistent between pits. The different behavior of nss $\mathrm{SO}_{4}=$ and MSA during the averaging process will be returned to shortly. For now we assume that the 3-pit means are a valid representation of the delivery of MSA and nss $\mathrm{SO}_{4}=$ to the region during 1987 - 1994.

The regional volcanic $\mathrm{SO}_{4}=$ concentration signal was estimated as: (Volcanic $\left.\mathrm{SO}_{4}{ }^{\prime}\right)=\left(\right.$ nss $\left.\mathrm{SO}_{4}{ }^{\circ}\right)-\mathrm{MSA} / \mathrm{R}$. This relationship should use $R^{*}$ rather than $R$, but if we knew what the biogenic $\mathrm{SO}_{4}{ }^{=}$contribution was a priori, this exercise would not be necessary. To account for the expected change in $R^{*}$ due to El Nino, we calculated mean values of $R$ for two periods; before and after 1991. To reduce the depression of $R$ relative to $\mathrm{R}^{*}$ by volcanic $\mathrm{SO}_{4}=$, we excluded the samples in the Pinatubo spike (24 - 30 on the common depth scale) when calculating the mean $\mathrm{R}$ for the recent period.

In the bottom of the profile it is apparent that simply averaging the 3 pits does not damp out sub-annual differences
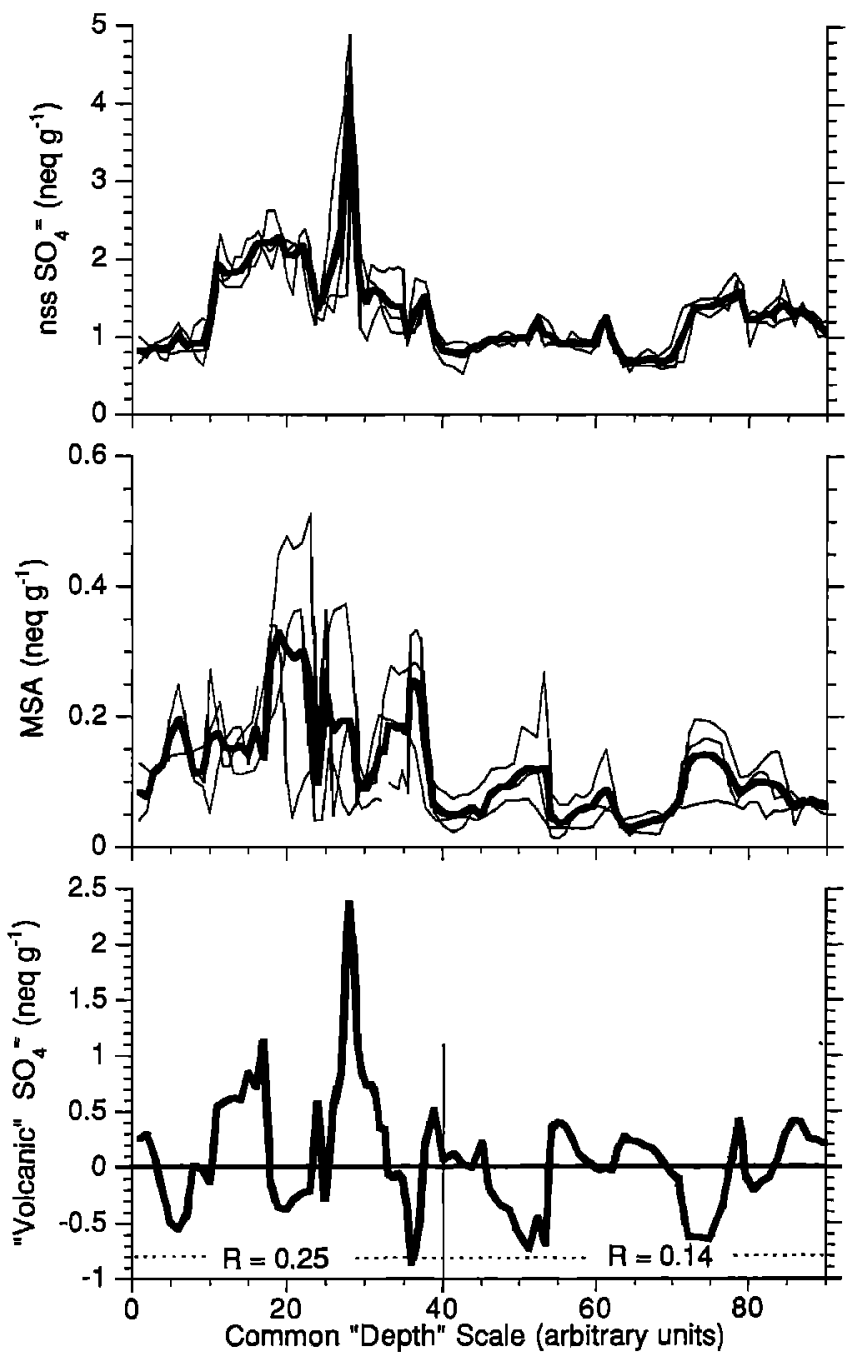

Figure 3. The 3-pit mean profiles of nss $\mathrm{SO}_{4}{ }^{2}$ and MSA are plotted on the common depth scale in the 2 upper panels (thick lines) with individual profiles included for comparison (thin lines). The lower panel shows "volcanic" $\mathrm{SO}_{4}=$ estimated from the mean nss $\mathrm{SO}_{4}=$ and MSA profiles (see text). 
in the timing of $\mathrm{SO}_{4}=$ and MSA delivery to the South Pole region, resulting in negative and positive estimates of volcanic $\mathrm{SO}_{4}=$ during a period when this component should be essentially absent (Fig. 3). This analysis does produce a clear volcanic signal in 1992, and a second peak in 1993. The 1993 peak indicates that the mean $R$ calculated for the top of the pit is a low estimate for $R^{*}$ due to the unrecognized volcanic component. Mathematically, we could optimize this approach by adjusting $\mathrm{R}$ and applying some temporal smoothing. However, it is not clear that the end result would be a valid estimate of volcanic $\mathrm{SO}_{4}=$ in the snowpack, and the uncertainty in the value derived would be large.

The different character of the MSA profiles in the 3 pits raises the concern that MSA concentrations in the snowpack may not directly reflect MSA concentrations in atmospheric aerosols or newly fallen snow. Thus it may be precarious to use $\mathrm{R}$ to estimate biogenic $\mathrm{SO}_{4}{ }^{=}$until the incorporation and preservation of MSA in Antarctic firn are better understood. These same issues have been recently raised, in light of observations of MSA apparently migrating out of layers of snow with relatively high $\mathrm{SO}_{4}=$ concentrations and into adjacent layers rich in sea-salt [Mulvaney et al., 1992; Wolff, 1995]. To date, no satisfactory explanation has been found for post-deposition migration of MSA, but it has been documented at 4 different coastal Antarctic sites [Wolff, 1995; K. Kreutz, personal communication, August, 1995]. The mechanisms operating at South Pole may very well be different than those at coastal locations due to the lower seasalt loadings, but it does not seem possible to invoke atmospheric transport and deposition processes to explain the magnitude of differences found in the MSA and R profiles from three South Pole pits that are so close together (Figs. 2 and 3).

\section{Conclusions}

Comparison of depth profiles of $\mathrm{NO}_{3}{ }^{-}$concentration in our 1994 pits to the profile in a pit sampled in 1988 indicates that post-deposition loss of $\mathrm{NO}_{3}{ }^{-}$is occurring in the upper 0.5 $1.0 \mathrm{~m}$ of firn at South Pole. Such loss must cast doubt on an earlier assertion that the $\mathrm{NO}_{3}{ }^{-}$profile at South Pole preserves a proxy record of $\mathrm{O}_{3}$ depletion in the Antarctic stratosphere. The period of record in the 1994 pits covers the years when the 6 deepest $\mathrm{O}_{3}$ holes yet measured occurred and no relation between $\mathrm{NO}_{3}{ }^{-}$concentration and the severity of $\mathrm{O}_{3}$ depletion can be discerned through the progressive depletion of $\mathrm{NO}_{3}{ }^{-}$in the upper layers of the snowpack.

These pits also cover the period when volcanic aerosols from eruptions at Hudson and Pinatubo appeared in the Antarctic stratosphere and the 1991 - 1993 extended El Nino event. The large nss $\mathrm{SO}_{4}=$ concentration spike in snow deposited in 1992, and some portion of the sustained high concentrations through 1993, must be volcanic, with Pinatubo probably making a larger contribution than Hudson. The El Nino event is recorded as a broad increase of both MSA concentrations and the ratio $\mathrm{MSA} /\left(\mathrm{nss} \mathrm{SO}_{4}{ }^{2}\right.$ ). Uncertainty about the variation of $\mathrm{MSA} /\left(\right.$ biogenic $\mathrm{SO}_{4}=$ ) at South Pole during El Nino events, plus poorly understood postdeposition modification of MSA concentrations in Antarctic snow, make it impossible to quantitatively partition the observed increase of nss $\mathrm{SO}_{4}=$ between volcanic and biogenic fractions at this time. We would suggest similar caution in the interpretation of other volcanic $\mathrm{SO}_{4}=$ signals in firn and ice from the Antarctic Plateau if they occur close to or coincident with El Nino events.

Acknowledgments. We thank P. Dunphy and the staff at South Pole for assistance in the field and L. D. Meeker for statistical help. This research was supported by NSF (OPP-9221836).

\section{References}

Cacciani, M., P. Di Girolamo, A. di Sarra, G. Fiocco and D. Fua, Volcanic aerosol layers observed by lidar at South Pole, September 1991 - June 1992, Geophys. Res. Lett.,20, 807-810, 1993

DeAngelis, $M$. and $M$. Legrand, Preliminary investigations of post depositional effects on $\mathrm{HCl}, \mathrm{HNO}_{3}$ and organic acids in polar fim layers, in, ed., R. J. Delmas, ce Core Studies of Global Biogeochemical Crcles, NATO ASI series I, vol. 30, 361-381, Springer-Verlag, Berlin Heidelberg, 1995.

Dibb, J. E., R. W. Talbot and M. H. Bergin, Soluble acidic species in air and snow at Summit, Greenland, Geophys. Res. Lett., 21, 1627-1630, 1994.

Herman, J. R., P. A. Newman, R. McPeters, A. J. Krueger, P. K. Bhartia, C. J. Seftor, O. Torres, G. Jaross, R. P. Cebula, D. Larko and $C$. Wellemeyer, Meteor 3/total ozone mapping spectrometer observations of the 1993 ozone hole, J. Geophys. Res.,100, 29732983, 1995.

Hofmann, D. J. and S. J. Oltmans, Anomalous Antarctic ozone during 1992: Evidence for Pinatubo volcanic aerosol effects, J. Geophys. Res., 98, 18,555-18,561, 1993.

Hofmann, D., S. J. Oltmans, J. A. Lathrop, J. M. Harris and H. Vōmel, Record low ozone at the south Pole in the spring of 1993, Geophys. Res. Lett., 21, 421-424, 1994.

Legrand, M. and C. Feniet-Saigne, Strong El Nino revealed by Methanesuphonic Acid in South Pole snow layers, Geophys. Res. Lett., 18, 187-190, 1991.

Maywski, P. A. and M. R. Legrand, Recent increase in nitrate concentration of Antarctic snow, Nature, 346, 258-260, 1990.

Mulvaney, R., E. C. Pasteur, D. A. Peel, E. S. Saltzman and P.-Y. Whung, The ratio of MSA to non-sea-salt sulphate in Antarctic Peninsula ice cores, Tellus, 44B, 295-303, 1992.

Saxena, V. K., J. Anderson and N. H. Lin, Changes in Antarctic stratospheric aerosol characteristics due to volcanic eruptions as monitored by the Stratospheric Aerosol and Gas Experiment II satellite, J. Geophys. Res., 100, 16,735-16,751, 1995.

Self, S. and G. A. Zielinski, Agung aerosols and the ice core record in 1963-64, (abst.) IUGG, XXI General Assembly, A267, 1995.

Whitlow, S., P. A. Mayewski and J. E. Dibb, A comparison of major chemical species seasonal concentration and accumulation at the South Pole and Summit, Greenland, Atmos. Environ., 26A, 20452054, 1992.

Wolff, E. W., Nitrate in polar ice, in, ed., R. J. Delmas, Ice Core Studies of Global Biogeochemical Cycles, NATO ASI series I, vol. 30, 195224, Springer-Verlag, Berlin Heidelberg, 1995.

Wolff, E. W., Location movement and reactions of impurities in solid ice, in, ed., E. W. Wolff and R. C. Bales, Processes of Chemical Exchange between the Atmosphere and Polar Snow, NATI ASI series I, (in press), 1996.

J. E. Dibb and S. I. Whitlow, Glacier Research Group, Institute for the Study of Earth, Oceans and Space, University of New Hampshire, Durham, NH 03824. (e-mail: jack.dibb@unh.edu; siw@unh.edu)

(Received January 5, 1996; Accepted March 15, 1996.) 